\title{
Hildreth Meière: Connections to Spain Before and During the Spanish Civil War
}

Mónica Orduña Prada

Universidad Internacional de La Rioja 

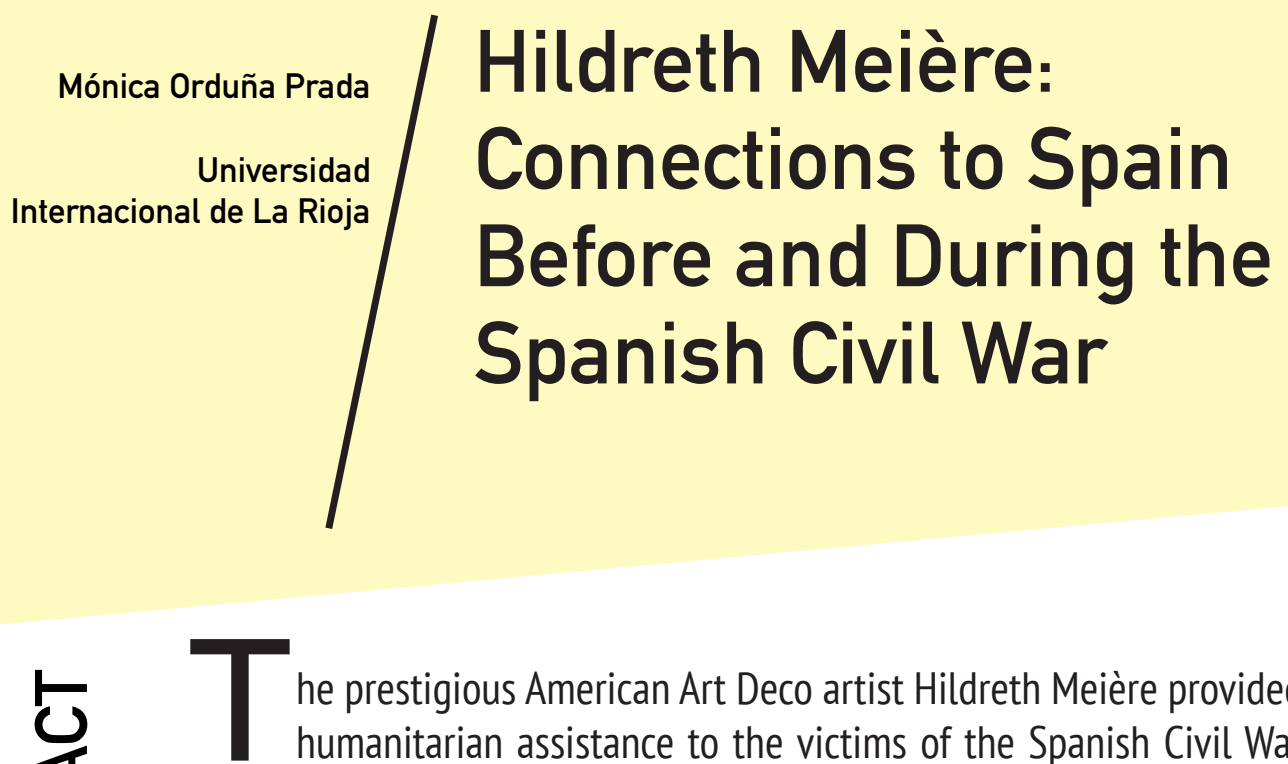

he prestigious American Art Deco artist Hildreth Meière provided humanitarian assistance to the victims of the Spanish Civil War and in the Second World War.Acting as the vice-president of the American Spanish Relief Fund created in 1937 and run by P. Francis X. Talbot, S. J. with the goal of helping people affected by the war in the Franco zone, and to also deliver medicine and medical supplies from the United States through diplomatic channels.

She visited Spain in 1925, 1938 and 1961. On the first trip she came to see the works of Spanish painters and made contact with important aristocratic families of the time (the Duke of Sotomayor, the Marquises of La Romana and Arcos, the Duchess of Vistahermosa, etc.). In 1938 she started humanitarian aid, collecting money and donations from New York society for orphans of the civil war and acted as a propaganda distributor for the Francoist cause in the United States. On this occasion she met with people familiar with the situation in Spain to solve the problems of humanitarian aid: Luis Bolín, Pablo Merry del Val, Cardenal Gomá, Carmen de Icaza, and Mercedes Sanz Bachiller.

Meière actively participated in providing humanitarian aid in the Franco zone during the years of the civil war while also acting as a staunch supporter of the Francoist cause. After the civil war she continued her collaboration to alleviate aid deficiencies in Spain by facilitating the transport of anesthetics, medicines, surgical materials, etc, but her

Orduña Prada, M. “Hildreth Meière: Connections to Spain Before and During the Spanish Civil War". REDEN. 1:1. (2019): 75-94. Web. 
perspective towards Francoism was changing and gradually her ties to Spain weakened. It was only three years before her death in 1961 that she made one last trip to Spain.

Key Words: Meière, Spanish Civil War, Humanitarian Assistance, Second World War

\section{INTRODUCTION}

Hildreth Meière was one of the most prolific American artists of the Art Deco period, with a career that lasted nearly up until her death in 1961. Born in New York, she had a studio in Manhattan. She was trained as an artist in Italy and in the art schools of New York, San Francisco, and Chicago. Besides being a pioneer in the application of different artistic techniques (especially murals) throughout her life, she won various prizes and awards and was the first woman admitted to the New York City Art Commission. Among her numerous art projects, she was commissioned eight projects for the Nebraska State Capitol and various church decorations, such as the mosaics in St.

\section{Hildreth Meière was one of the most prolific American artists of the Art Deco period.}

Bartholomew's Church on Park Avenue in New York City, the ceramic in the ceiling of The University of Chicago's chapel, the reredos in St. Paul's Chapel of Cranbrook, Michigan, and the mosaics in the Temple Emanu-El in New York City. She also designed or painted decorations for various banks and theaters, the Radio City Hall in Manhattan and the Rockefeller Center Promenade Café1.

On her first trip to Spain in the 1920's, not only did she establish family contacts, her artistic side led her to discover some of the artistic landmarks in Spain such as the Prado Museum or the Monastery of El Escorial. She also visited some private collections of portraits of Spanish aristocracy. As she did throughout her life on numerous trips around the world in search of new artistic skills, learning new painting techniques and discovering new artists were all reasons for her travels to Spain.

Apart from her artistic life which was studied in detail by Coleman and Murphy, from 1936-1945 Meière was deeply devoted to organizations that benefited civilian victims of the Spanish Civil War and the Second World War. Her dedication to such organizations had important links, especially in the case of the Spanish conflict, to her identity as a practicing Catholic. She was involved (often with a role such as a vice president or treasurer) with many humanitarian aid groups, one of them being the American Spanish Relief Fund, the Committee to Send Medicines and Anesthetics to Spain, and the French Civilian Relief. 


\section{She was involved with many} humanitarian aid groups, one of them being the American Spanish Relief

Fund, the Committee to Send

Medicines and Anesthesics to

Spain, and the French Civilian Relief. 
It will be necessary for this study to explain what the American Spanish Relief Fund was. It was founded in May of 1937 with the idea of giving aid to the people most affected by the war in the Franco's Zone and was run by a Jesuit priest named Francis X Talbot. The goals were to "Collect funds to be used for medical aid and assistance in Spain or for food or clothing" (Talbot, Letter to Secretary of State Cordell: 2) ${ }^{2}$.This assistance was primarily destined for Franco's Spain because, as Father Talbot himself pointed out in a request for funds "The proceeds will be applied to the American Spanish... While the Leftists and Communists are sending over hundreds of thousands of dollars to Red Spain, we Catholics have contributed only a few thousands of dollars for our people in White Spain" (Talbot, Letter: n. p.).

This organization was established after the creation of the American Committee for Spanish Relief which had emerged in the shadow of the American Catholic bishops and whose donations were sent to the Red Cross for later distribution in Spain. However, donations made to the American Spanish Relief Fund were both used and distributed by the Spanish ecclesiastical hierarchy (González Gullón 322).

\section{The goals were to "Collect funds to be used for medical aid and assistance in Spain or for food or clothing".}

And the Committee to Send Medicines and Anesthetics to Spain was founded in June of 1940 during the Spanish post-war period "to send medicines, drugs, anesthesics, vitamins, etc., to Mr. and Mrs. Alexander Weddell for distribution through the American Embassy in Madrid" (Meière 1942: 2) ${ }^{4}$. The idea was that the United States would obtain medicine and send it to Spain through diplomatic channels. Taking into account the dramatic situation and the shortages in Spain, it was logical that supplies were asked for instead of money. Having the funds did not guarantee that Spain could buy medicine.

2 Rev. Francis X. TALBOT, S.J. Letter to Secretary of State Cordell (May 11, 1937), Georgetown University Library. America Magazines Archives. Spain Material-America Spanish Relief Fund (1936-1937), Box 20, folder 16.

3 Rev. Francis X. TALBOT, S.J. Letter (November, 10, 1937), Georgetown University Library. America Magazines Archives. Spain Material-America Spanish Relief Fund (1936-1937), Box 20, folder 18

${ }^{4}$ Dissolution of the Committee to Send Anesthetics and Medicines to Spain, December 8,1942. Hildreth Meière papers, 1901, bulk 1911-1960. Archives of American Art, Smithsonian Institution. Box 5, folder 5.35, (2 of 2). Civilian War Service Records. Spanish Civil War. Committee to Send Anesthetics and Medicines to Spain, (1940-1943). 
The official position of American Catholics in relation to the Spanish civil war and the parties to the conflict was formed during the National Catholic Welfare Conference (NCWC) with US bishops. However, it was Catholic newspapers and magazines, with some exceptions, who carried out propaganda tasks for the Franco regime among Catholics (González Gullón 21).

One of the best examples was America Magazine which, during the years of the Spanish Civil War, was not only a platform for the transmission of anti-communist slogans and texts in favor of Franco's Spain, but also published editorials, announcements, or letters from the editor with requests for donations and funds to help Spanish Catholics.

\section{Meière was a tireless traveler who toured nearly the whole world during her life.}

Meière was a tireless traveler who toured nearly the whole world during her life. She made three trips to Spain, the first being largely related to a relationship she had established with a part of Spanish society, namely her family. Her visits to Spain took place during three distinct moments: under the dictatorship of Primo de Rivera in 1925, during the Civil War in 1938, and finally under the Franco regime in $1961^{5}$. This paper examines what Meière perceived regarding the reality of Spanish society during the two significant periods in Spanish history in which she visited Spain, specifically her the first two visits in 1925 and 1938. It also examines the family connections she established which were fundamental in her decision to become involved with humanitarian aid during the Civil War.

\section{FIRST CONTACT WITH SPAIN}

In 1925, with the approval of King Alfonso XIII, the first stage of the dictatorship of Primo de Rivera (a military directorate) gave way to a Civil Directorate in an attempt by the dictator to institutionalize the regime. This same year the regime also started to take measures to boost the political and economic life of Spain (Jover Zamora, Gómez-Ferrer \& Fusi 563).

${ }^{5}$ Regarding her third visit, in the Hildreth Meière archives there is no written documentation of this trip, only photographs and slides of her visits to cities such as Granada or Sevilla. 
The first objective of Hildreth Meière in her visit to Spain in April of 1925 was to see firsthand some of the primary Spanish monuments and the works of great Spanish painters so as to continue her artistic training in different techniques. Meière also wished to establish contact with members of the Spanish aristocracy she was related to. Her visit to Spain was preceded by a letter addressed from her uncle Thomas McKean Meière to the Duke of Sotomayor,Pedro Martínez de Irujo. This letter not only announced the visit of Meière and communicated her interest in the portraits of Gilbert Stuart which the Duke owned, but it also let them discover their family connections. In fact, they were kin of Thomas McKean, one of the signers of the Declaration of Independence of the United States, represented by the Count of Delaware and later the Governor of Pennsylvania. In addition to detailing issues about the branches of the family tree that they had in common, McKean invite the Duke to visit the United States mentioning,"and if you should do so, I, and your many cousins here, would certainly like the pleasure of seeing you in Baltimore" (McKean 2) ${ }^{6}$.

Meière and Louise Hamilton (her friend which accompanied her on the trip) were received by the Duke of Sotomayor and with him they called on various family members and visited the Prado Museum, The Royal Site of San Lorenzo de El Escorial, the Monasterio de Guadalupe, and Toledo. Besides her visit to the Prado Museum which made an impact on her as an artist, another activity that interested her greatly was attending a polo match at the Club de Campo Villa de Madrid. There she had the opportunity to meet, thanks to the Duke, members of the royal family? Specifically, she met Infanta Isabella, the Prince of Asturias, and the Queen which she described

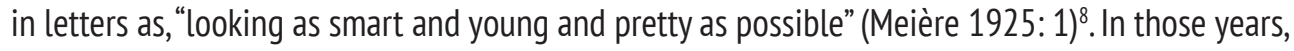
despite the fact that Alfonso XIII as King was not exempt from controversy or difficulties (Seco Serrano), the presence of the royal family in Madrid's social life was something quite habitual though it was still very surprising to the American artist.

The correspondence that Meière maintained with her family in the United States during her visit mainly consisted of descriptions of new family members she met in Spain, along with some mentions of places she had visited such as Segovia or Burgos. Apart from mentioning the Duke, his wife, and some of his children, she also met other family members such as the Marquesses of Romana, the Maquis of Aros, the Marques of Lamberty, and the Duchess of Vistahermosa. The latter,

\footnotetext{
${ }^{6}$ Letter from Thomas McKean to the Duke de Sotomayor, March 23,1925. Hildreth Meière papers, 1901, bulk 1911-1960. Archives of American Art, Smithsonian Institution, Box 3, folder 3.35. HM correspondence with Spanish Relatives, 19251939.

${ }^{7}$ She had previously expressed her interest to the Duke,"I said I was very anxious to see the King, and the Duke said he would take us to the polo on Saturday". Letter from Hildreth Meière to Thomas McKean,April 10,1925. Hildreth Meière papers, 1901, bulk 1911-1960. Archives of American Art, Smithsonian Institution, Box 3, folder 3.35. HM Correspondence with Spanish Relatives, 1925-1939.

${ }^{8}$ She had previously expressed her interest to the Duke,"I said I was very anxious to see the King, and the Duke said he would take us to the polo on Saturday”. Letter from Hildreth Meière to Thomas McKean, April 10,1925. Hildreth Meière papers, 1901, bulk 1911-1960. Archives of American Art, Smithsonian Institution, Box 3, folder 3.35. HM Correspondence with Spanish Relatives, 1925-1939.

${ }^{9}$ Letter from Hildreth Meière to Thomas McKean,April 10,1925. Hildreth Meière papers, 1901, bulk 1911-1960.Archives of American Art, Smithsonian Institution, Box 3, folder 3.35. HM correspondence with Spanish Relatives, 1925-1939.
} 


\section{The first objective of Hildreth Meière in}

her visit to Spain in April of 1925 was to see firsthand some of the primary Spanish monuments and the works of great Spanish painters. 


\section{In the same way the relationships forged during this initial foray were crucial in converting Meière into an active defender of the Francoist cause during the Spanish Civil War.}


sister of the Duke of Sotomayor, was described by Meière as someone, "who is a Lady-in-waiting to the Queen Mother, and she would try to get all the Mckean descendents to meet me" (Meière 1925: $2)^{9}$.

For an American in the 1920's, the experience of meeting members of the Spanish aristocracy, some of which she was related to, suddenly became more important than the artistic pursuits that had originally inspired her trip. In fact, the documents surrounding Meière includes numerous letters where she describes her various trips around the world, the countries she visited, and the economic, social, and politica ${ }^{10}$ climate of each as well as various works of art that she felt could serve as a reference for her artistic techniques. However, in her first visit to Spain are no such references.

In reality this first contact with Spain permitted her to establish a connection which resulted in a rich correspondence with some members of the Martínez de Irujo family, especially Pedro de Sotomayor and Isabel de Vistahermosa, with which whom she exchanged information about the situations in both Spain and the United States starting in the year 1925. In the United States they referenced the economic crisis which gave rise to the Great Depression and in the case of Spain they mentioned the supposed arrival of the Republic and some of the key events surrounding it such as the revolution of October $1934^{11}$.

In the same way the relationships forged during this initial foray were crucial in converting Meière into an active defender of the Francoist cause during the Spanish Civil War and was also the impetus for her second visit to Spain.

\section{MEIÈRE AND SPANISH CIVIL WAR}

Meière's second visit to Spain took place during the war, in August of 1938. She was acting as a representative of the American Spanish Relief Fund. This trip, in addition to allowing her to reunite with her family, was fundamental to her humanitarian activities. Up until this visit, Meière had carried out an important role in collecting funds and donations among New York society with the aim of assisting orphaned children by the Spanish Civil War and as a promoter of the Francoist cause in the United States. It was usual for her that during that period to have gatherings in her

\footnotetext{
${ }^{9}$ Letter from Hildreth Meière to Thomas McKean,April 10,1925. Hildreth Meière papers, 1901, bulk 1911-1960.Archives of American Art, Smithsonian Institution, Box 3, folder 3.35. HM correspondence with Spanish Relatives, 1925-1939.

${ }^{10}$ For example in 1934 while she was doing some paintings in Baviera (Germany), she wrote to some friends in the United States relating with detail the sensation that she noted in the Germans who were anticipating a visit from Hitler. Apart from being a complete physical description, Meière indicated "I suppose I have the average American attitude and antagonism and prejudice about him, but I admit I was rather impressed by him [...] It's as though Lindberg at his greatest popularity and Babe Ruth were combined and had been elected President at home". Letter from Hildreth Meière to Ellie Lloyd, August 13, 1934. Hildreth Meière papers, 1901, bulk 1911-1960. Archives of American Art, Smithsonian Institution, Box 3, folder 3.65. Correspondence Business.

${ }^{11}$ Isabel de Vistahermosa wrote "We had a very bad time all over the country since October last". Letter from Isabel de Vistahermosa to Hildreth Meière, January 27,1935. Hildreth Meière papers, 1901, bulk 1911-1960. Archives of American Art, Smithsonian Institution, Box 3, folder 3.41. Correspondence with Spanish contacts.
} 
studio, which were attended by architects, other artists, and members of New York high society. At times Father Talbot attended himself and made fierce defenses of the Francoist cause, influenced by his Catholic formation with anti-communist influences ${ }^{12}$.

It must be taken into account that the news that arrived in the United States about the Spanish Civil War and its effects on civilians gave rise to an important mobilization between different sectors of society.

The position of the Roosevelt administration was largely responsible, as pointed out by several scholars ${ }^{13}$ because not only did they maintain an embargo on the sale of arms (Thomàs), they also made it difficult to provide any sort of humanitarian aid to Spain. The neutrality policy which the Roosevelt administration had maintained since the beginning of the Civil War was questioned a year later, and there was an intense debate between pro-loyalists and American Catholics who supported Franco. In the case of Catholics, it was especially evident from the National Catholic Welfare Conference, the body responsible for official positions and in relation to the conflict. The Roosevelt administration's defense in the maintenance of neutrality was reflected in the publication of a memorandum which reached a wide audience $e^{14}$.

Thus mobilization took place around associations and organizations of a humanitarian nature. Some groups refused to take sides and provided humanitarian aid from a neutral stance, such as the Quakers. The lack of public funds and government support from the United States to finance humanitarian aid destined for Spain were deciding factors for these associations and organizations to carry out the important tasks of collecting donations and delivering food, clothing and humanitarian material in general (Smith).

Meière was able to enter Spain during a moment in which the State Department was especially especially selective when granting passports and permits to travel to Spain because she was traveling as a representative of the American Spanish Relief Fund. The passport request was submitted by Father Talbot as the head of the humanitarian organization ${ }^{15}$. Francis X Talbot was editor of American Magazine between 1936 and 1944 and during years of Spanish conflict he was a strong defender of the Francoist cause, publishing numerous articles in which he mixed his Francoist sympathies with anti-communist Americanism (Chapman). Talbot's close relationship with the diplomat Juan F. de Cárdenas should also be taken into account. Cárdenas acted as the official agent of Franco's government in the United States and was a supporter of America

\footnotetext{
${ }^{12}$ Although in 1934 during a stay in Germany she traveled to Oberammergau specifically to see Hitler's entrance at a rally, there is no record that possible fascist influences were decisive in her support for the Francoist cause. Although she acknowledged that she was impressed by the paraphernalia and the environment in which people were waiting for the Führer, she indicated that "I suppose I have the average American attitude and antagonism and prejudice about him." Letter from Hildred Meière to Ellie Lloyd, August 13, 1934. Hildreth Meière papers, 1901, bulk 1911-1960. Archives of American Art, Smithsonian Institution, Box 3, Folder 3.65. Correspondence Business.

${ }^{13}$ This can be verified in Bosch (2012) o Merino (2017).

${ }^{14}$ Memorandum in support of the retention of the Spanish Embargo". Washington, The Catholic University of America. 1939. Library of Congress, Washington D.C Fondo Harvard Library College, Spanish Civil War, microform 84/3771

${ }^{15}$ This is stated in the letter addressed to the State Department with the request. Letter from Francis Talbot to R. B. Shipley.June 11,1938. Hildreth Meière papers, 1901, bulk 1911-1960. Archives of American Art, Smithsonian Institution, Box 5, Folder 5.31. Civilian War Service Records. Spanish Civil War. Correspondence, 1938
} 


\section{She was traveling \\ as a representative} of the American Spanish Relief Fund. 


\section{Since Meière was a}

supporter of Franco

she considered it a very

important trip because

it would allow her to

return to the United

States to offer first-

hand information about

Franco's Spain after

touring different cities. 
Magazine. He even suggested that Father Talbot and his colleagues travel to the Francoist zone of Spain "by explaining how Franco was simply attempting to rid Spaniards of a Videous Soviet-direct government” (Chapman 20).

Traveling to Spain from certain countries during the war was complicated. Because the United States had declared a moral embargo, Britain and France had taken positions of nonintervention, and the Spanish Embargo Act had been signed in early 1937 (López Zapico 88), the State Department required that all travelers to Spain register themselves (Del Rey 119). Meière's passport stated she was "[...] a relief worker on assignment to Spain, and this Passport is therefore valid for travel in that country"16. The organization of the trip, the journey through Franco's Spain, and the contacts in the United States were obtained via the official agent of Franco's government in the United States: Juan Francisco de Cárdenas ${ }^{17}$.

Meière had three goals on this trip. The first was personal in nature; she wanted to find her Spanish relatives and see how they were doing in the midst of the conflict.

"I heard that Pedro was a hostage at Bilbao for months; that Maria and Christine were in Embassies as refugees; and that one of the Vistahermosa sons was in hiding in Madrid. They've all gotten out now-except the boy who is an Embassy; but Pedro's oldest son has been killed" (Meiére 1938: 7$)^{18}$.

In regards to her other goal on the journey, since Meière was a supporter of Franco she considered it a very important trip because it would allow her to return to the United States to offer first-hand information about Franco's Spain after touring different cities. She considered this crucial in order to get Americans to support Franco. In fact, during her visit even the Duke of Sotomayor supported her in disseminating propaganda: "I am delighted that after your visit to Spain, you are able to give conferences about our real situation" (Sotomayor 1$)^{19}$.

Her last goal was what truly linked her work to providing humanitarian aid through the American Spanish Relief Fund. Meiére interviewed Cardinal Gomá and discussed with him the use of the different funds that were being sent from the United States and how the association was carrying out humanitarian aid.

The journey of Meiére into Franco's Spain took place between August $8^{\text {th }}$ and $20^{\text {th }}, 1938$. During this time she visited places such as Irún, San Sebastián, Burgos, Valladolid, Ávila, Leganés,

\footnotetext{
${ }^{16}$ Passport, 1938. Hildreth Meière papers, 1901, bulk 1911-1960. Archives of American Art, Smithsonian Institution, Box 5, Folder 5.14. Writings. Prose, Spanish Civil War.

${ }^{17}$ As she wrote to a friend in France, "He gave me a letter to give to the officer in charge of the frontier at Irún". In a letter from Hildreth Meière to Marina Hoffman. June 27,1938. Hildreth Meière papers, 1901, bulk 1911-1960. Archives of American Art, Smithsonian Institution, Box 3, Folder 3.44. Correspondence Travels. 1938. And as she explained to her daughter, "Cárdenas has written to Burgos about me and has given me several letters of introduction”. Travel diary, 1938. Hildreth Meière papers, 1901, bulk 1911-1960. Archives of American Art, Smithsonian Institution, Box 5, Folder 5.14. Writings. Prose, Spanish Civil War.

${ }^{18}$ Travel diary, August 9, 1938. Hildreth Meière papers, 1901, bulk 1911-1960. Archives of American Art, Smithsonian Institution, Box 5, Folder 5.14. Writings. Prose, Spanish Civil War.

${ }^{19}$ Letter from the Duke of Sotomayor to Hildreth Meière, December 14,1938. Hildreth Meière papers, 1901, bulk 19111960. Archives of American Art, Smithsonian Institution, Box 3, Folder 3.41. Correspondence Travels.1938.
} 
Toledo, Salamanca, Bilbao, Durango and Guernica. She entered Spain through Hendaye and faced one final difficulty in her trip: she needed permission from the then United States Ambassador to Spain, Claude Bowers ${ }^{20}$, who had installed the US embassy in Saint-Jean-de-Luz for a visa granting special to access to Spain from France.

After passing through Irún, she went to San Sebastián where she met the Duke of Sotomayor after three years apart. Besides inquiring about the welfare of the different members of the Martínez de Irujo family, she explained to him the goals of her trip and "the sort of information I wanted to gather about Welfare Work and what I needed by way of help" (Meière 1938: 43) ${ }^{21}$.

The Duke of Sotomayor, through means of a diplomat, was able to obtain Meière an interivew with Luis Bolín who was then the head of the National Tourism Service.She also conveyed her interest in interviewing Cardinal Gomá to obtain statistics on the number of orphaned children in the Franco zone and her desire to learn about the needs of children in that area. She also indicated that "I wanted to see, not war horrors but the constructive side of National Spain and to meet people who were directing the social work" (Meière 1938: 44)22.

With the help of Luis Bolín she obtained a pass from the Office of Press and Propaganda and made the first visit to a humanitarian aid institution in Franco's Spain, specifically, an Auxilio Social organization known as The Brotherhood Kitchen. They distributed take-home meals in special containers for the financially needy or sick people (Orduña). Meière described it as "a combination of social service, relief and war-time canteening" (Meière 1938:46) ${ }^{23}$.

Meière established a friendly relationship with the diplomat's wife and together they carried out a welfare visit that, although it cannot be confirmed from her account, was most likely through the Delegación Nacional de Frentes y Hospitales since they went to the General Mola Military Hospital where they distributed tobacco among wounded soldiers and wounded prisoners. This hospital was a leader in the field of surgery and anesthesia and had on its team one of the most prestigious American surgeons who collaborated with the Francoist troops in the rearguard, specifically Dr. Joseph Eastman Sheehan, who organized what was the first plastic surgery service in Spain in this hospital ${ }^{24}$.

To get a better idea of the depth of Auxilio Social, Meière also visited Valladolid where it was founded October 1936, where she had meetings with then General Secretary Carmen de Icaza and with the founder of Auxilio Social Mercedes Sanz Bachiller. Before leaving Spain she also visited a residence for girls taken in by Auxilio Social in Lekeitio. This allowed Meière to approach

\footnotetext{
20 In 2019 the memories of Ambassador Bowers have been reissued in which his mission during the Spanish Civil War from Saint-Jean-de-Luz is detailed (Bowers 2019).

${ }^{21}$ Travel diary, August 9, 1938. Hildreth Meière papers, 1901, bulk 1911-1960. Archives of American Art, Smithsonian Institution, Box 5, Folder 5.14. Writings. Prose, Spanish Civil War.

${ }^{22}$ Travel diary, August 9, 1938. Hildreth Meière papers, 1901, bulk 1911-1960. Archives of American Art, Smithsonian Institution, Box 5, Folder 5.14. Writings. Prose, Spanish Civil War.

${ }^{23}$ Travel diary, August 9, 1938. Hildreth Meière papers, 1901, bulk 1911-1960. Archives of American Art, Smithsonian Institution, Box 5, Folder 5.14. Writings. Prose, Spanish Civil War.

${ }^{24}$ Sheehan studied at Yale, completing his training in cities such as Bern, Paris, London and Heidelberg. (Expósito\& Rubio\& Solórzano 2012).
} 


\section{To get a better idea of the} depth of Auxilio Social, Meière also visited Valladolid where it was founded October 1936. where she had meetings with then General Secretary Carmen de Icaza and with the founder of Auxilio Social Mercedes Sanz Bachiller. 
different institutions where humanitarian aid was being provided in the Franco zone and enabled her to acquire information to allow the United States to spread propaganda of the regime.

By way of Pablo Merry del Val, chief of correspondents in the National Press Service with whom she had a meeting in Burgos, helped get a meeting with Cardinal Gomá in Toledo. Through Pablo Merry del Val, chief of correspondents in the National Press Service with whom she had met with his Burgos, Meiére was able to obtain a meeting with Cardinal Gomá in Toledo. In writing about this meeting, Meiére, who did not normally record minute details, recorded that with the money sent to him, the Cardinal "divides it into three parts: one for children, one for the priests and nuns, and the third for those who are in desperate need and appeal to him"25.

However, there are documents sent by Cardinal Gomá to Father Talbot specifying the amounts sent to different zones of Spain divided into three groups. According to the dioceses their purpose was to alleviate the needs of children orphaned by war and needy people in general.

During her stay in Toledo Meière was able to visit and film the ruins of the Alcázar from both the inside and outside thanks to the permits and safe passages that Merry del Val had facilitated as both a photographic and cinematographic foreign journalist. The visit made a deep impression on her and she describes in her diary practically everything she saw, from the statue of Carlos V, the empty swimming pool they used to bury the dead, the areas that they took refuge from bombs in, or for example indicated that "Here and there were crude crosses, marking spots where different men were killed" (Meière 1938: 46) ${ }^{26}$.

Meière continued her journey through different cities such as Ávila and Salamanca with the intention of visiting the different members of the Martínez de Irujo family, such as María Martínez de Irujo, the Viscount of Manzanera or Isabel de Vistahermosa. Ever a fan of art, she visited the Cathedral of Salamanca and the Cartuja de Burgos. She also met the painter Ignacio de Zuloaga and admired his sculptural and paintings.

During her stay in Spain she took numerous photographs and also filmed footage in addition to the materials she requested from the photography department of the Delegation of Press and Propaganda ${ }^{28}$. All of this she sent to the United States along with propaganda posters that she could not take with her to the France because French officials at the border called them "fascist propaganda" (Meière 1938: 184) ${ }^{29}$.

\footnotetext{
25 Travel diary, August 14, 1938. Hildreth Meière papers, 1901, bulk 1911-1960. Archives of American Art, Smithsonian Institution, Box 5, Folder 5.14. Writings. Prose, Spanish Civil War.

${ }^{26}$ Travel diary, August 15, 1938. Hildreth Meière papers, 1901, bulk 1911-1960. Archives of American Art, Smithsonian Institution, Box 5, Folder 5.14. Writings. Prose, Spanish Civil War.

${ }^{27}$ Travel diary, August 9, 1938. Hildreth Meière papers, 1901, bulk 1911-1960. Archives of American Art, Smithsonian Institution, Box 5, Folder 5.14. Writings. Prose, Spanish Civil War.

${ }^{28}$ Meière was very clear in the face of her propaganda action in the United States regarding the subjects of the photographs that would help her cause "Red murders, Martyrs and Personalities, Ruined Churches, Leaders, Hospitals, Auxilio Social and Falange”. Travel diary, August 17,1938 p.141. Hildreth Meière papers, 1901, bulk 1911-1960. Archives of American Art, Smithsonian Institution, Box 5, Folder 5.14. Writings. Prose, Spanish Civil War.

${ }^{29}$ Writings. Prose, Spanish Civil War. Travel diary,August 20,1938. Hildreth Meière papers, 1901, bulk 1911-1960.Archives of American Art, Smithsonian Institution, Box 5, Folder 5.14. Writings. Prose, Spanish Civil War.
} 
Although not addressed in this article, she later used the photographs and footage gathered in Spain to aid her in the telling of her experiences in meetings with members of the American Spanish Relief Fund, on radio broadcasts, or in conferences with the goal of praising the virtues of the new regime that arose from the war and to obtain funds for the provision of humanitarian aid.

\section{CONCLUSIONS}

A prolific artist such as Hildreth Meière, with a manifest interest in travel and cosmopolitan in almost every way, offers several perspectives for studying and analyzing her different activities. One of the most interesting aspects of her life was the relationship she maintained with Spain and the links she established with the United States. Those links were, during the late twenties, of a strictly family and personal nature and broadened considerably during the Spanish Civil War.

From the beginning of the conflict in Spain, Meière quickly decided to support Franco's cause and to collaborate from a humanitarian standpoint. This, combined with the news she received from her relatives and her practicing Catholicism, could also have influenced her intense participation with Father Talbot not only with the American Spanish Relief Fund but also in an organization called the American Union for Nationalist. Merwin K. Hart, the founder of the New York State Economic Council, was president of both organizations and was also the founder of the American Union for Nationalist. He also traveled to Spain after Meière in October 1938 and published a book about his experience.

Meière was a staunch advocate for the Francoist cause and during her visit to Spain she demonstrated great interest in constructing a story of what she saw in order to later spread Francoist propaganda throughout the United States and acquire American allegiance to the new regime that was dramatically being imposed in Spain. In fact, although her trip was permitted by US authorities because of the humanitarian factor, the only humanitarian aspect to the trip was her visit with Cardinal Goma who was the recipient and distributor of the aid from the American Spanish Relief Fund.

Meière met with the highest Spanish ecclesiastical hierarchy in order to learn more about the fate of the funds from American Catholics in Franco's Spain. The visits she made to institutions such as Social Assistance or the Women's Section, rather than verifying the proper use of money from the American Spanish Relief Fund, were, according to her own diary and notes, to praise the work of Franco and exalt figures like Pilar Primo de Rivera or Mercedes Sanz Bachiller.Furthermore, when she arrived in Franco's Spain, the safe-passage was given to her as a foreign photographic and cinematographic journalist.

Additionally, a large part of the places visited by the artist played important roles in Francoist propaganda. For example, she visited Alcázar de Toledo, the story of which was one key forms propaganda and one of the most important sociological myths of Francoism. Also the images she solicited from the Delegation of Press and Propaganda combined her interest of what she saw as achievements of the regime with the destruction on the part of the Republicans. This is why she 
was especially interested in pictures of churches destroyed by Republicans and pictures of dead priests in order to generate ill-will in American Catholics towards the Republic, combining it with the anti-communism that formed part of the ideology of most American Catholics at the time.

Although her collaboration through humanitarian aid to Spain didn't end with the war as she continued facilitate the acquisition of anesthesia, medicines, different surgical materials and clothing to the Spanish population through the United States Embassy in Spain, her perspective on Francoism did change. In 1942 when the United States had entered into the Second World War she acknowledged in a letter to Javier Gaitán de Ayala, representative of the United States Spanish Library of Information, that despite her initial support for the Francoist cause at start of the Spanish Civil War and her humanitarian relief efforts, she strongly opposed the presence of Falange and the regime because of the similarities she saw with the Nazi party.

After the end of the civil war and her subsequent change of opinion regarding the Franco regime, her ties to Spain were gradually diminished and she only made one more trip to Spain in 1961 before her death in 1964.

Testimonies of individuals disengaged from violent extremism are important to prevent the process of radicalization, testimonies of victims of terrorist attacks. Interreligious activities, fomenting interculturality, involve students' families, working at community-local and municipal level, promote the role of women in the prevention of extremism, control radical speeches and collaborating in projects with mosques, preventing radicalization in prisons with specific programs. Advice through campaigns of the danger of the false online profiles and chats of extreme right, left and religious individuals and organizations. Work in the deconstruction of islamist radical discourses through Islamic law. Keep working on counter-narratives through the internet and in educational centers (Jalloul, 2017).

Putting in force a proper guideline for the prevention of radicalization that leads to violence within governments' policies would mean that we understand the needs of our societies in a successful way, that we fight against violent extremism and terrorism, that we simply fight against the fear of the unknown.

\footnotetext{
References

Bosch, A. Miedo a la democracia. Estados Unidos ante la Segunda República y la Guerra civil española. Barcelona: Crítica, 2012. Print.

Bowers, C. Mi misión en España. En el umbral de la Segunda Guerra Mundial Prólogo de Ángel Viñas. Madrid: Arzalia Ediciones, 2019. Print.

Chapman, M. Arguing Americanism. Franco Lobbysts, Roosevelt's Foreign Policy and the Spanish Civil War. Kent: The Kent State University Press, 2011. Print.

Coleman, C. \& K. Murphy. The Art Deco Murals of Hildreth Meière. New York: Andrea Monfried Editions, 2014. Print.

Del Rey, M. “Los españoles de los Estados Unidos y la guerra civil (1936-1939)". REDEN. Revista Española de Estudios Norteamericanos 7.(1994): 107-120. Web.

Expósito, R., J. Rubio \& M. Solórzano. “Historia de una escuela que se convirtió en hospital”. Enfermería Avanza.January 2012. Web.

González Gullón, J. L. "La guerra civil española y la conferencia de obispos norteamericana”. Hispania Sacra 64:1.(2012): 315-341. Print.
} 
Jover Zamora, J. Ma , G. Gómez Ferrer \& J. P. Fusi. España: sociedad, política y civilización (siglos XIX-XX). Barcelona: Random House Mondadori, 2001. Print.

López Zapico, M. Las relaciones entre Estados Unidos y España durante la guerra civil y el primer franquismo (1936-1945). Gijón: Trea, 2008. Print.

Meière, H. Hildreth Meière papers, 1901-2011, bulk 1911-1960. Archives of American Art, Smithsonian Institution.

Memorandum in support of the retention of the Spanish Embargo. Washington, The Catholic University of America. 1939. Library of Congress, Washington D.C Archive of the Harvard Library College, Spanish Civil War, microform 84/3771

Merino,J.C."The first months of the Spanish Civil War in the United States of America". Historia Actual on line 42. (2017): 35-43. Web.

Orduña Prada, M. El Auxilio Social (1936-1940). La etapa fundacional y los primeros años. Madrid: Escuela Libre Editorial/Fundación ONCE, 1996. Print.

Seco Serrano, C. Alfonso XIII. Madrid: Arlanza, 2001. Print.

Smith, E. American Relief Aid and the Spanish Civil War. St Loius: University of Missouri, 2013. Print.

Thomàs,J. Ma . Roosevelt y Franco. De la guerra civil española a Pearl Harbour. Barcelona: Edhasa, 2007. Print. 